\title{
Embodying the Elements within Nature through the traditional Malay art of Silat Tua
}

\section{Lian Sutton}

LASALLE College of the Arts, Singapore

\begin{abstract}
The paper introduces Silat Tua, a traditional Malay martial art, and its relationship to the tropics of the Malaysian Peninsula and Singapore through the imagery work of the four Elements: Earth, Water, Fire, and Wind. In a world of increasing disconnect between Humans and Nature, the Silat Tua practice is a traditional martial art for bringing harmony and healing, as well as an understanding of how the building blocks of Nature can harmonise, complement and resonate with the natural resources of the human mind, body and spirit. Through recounting the legend of the art's origin, the first proponent of Silat Tua is shown to have gained inspiration and lessons from the inhabited environment. Examples of how a Silat exponent may explore and come to understand the Elements are discussed before venturing into the practical application of the Elements in cultivating mindfulness and influencing behaviour. The physical environment thus, is not only a source of inspiration for movement but indeed an impetus for leading a harmonious and virtuous life. The paper concludes with the connection and implications of the Elements training in Singapore and its potential in navigating oneself through the constant changes inevitable in life.
\end{abstract}

Keywords: Silat Tua, Nusantara Martial Arts, The Four Elements, Nature, 
$S$ ilat Tua is a traditional Malay martial art, and like most of its kind, it paradoxically highlights the value of life through the development of techniques for the purpose of harming the life of another (Sutton L., 2014, p. 5). It is an art that has an intimate relationship with nature, as understood from its roots in animism (Zainal Awab \& Sutton, N. 2007, p. 13). Through understanding the art, this paper uncovers the origins and applications of the four Elements in Silat Tua practice and its relationship with Singapore, a modern multicultural metropolis. The art itself frees the imagination, inspires movement and self-reflection, all leading to a deeper understanding of the exponent's self and interaction with his or her immediate environment. This paper is based on personal experience of the author who has undertaken rigorous training in Silat Tua for over a decade attaining a high level of proficiency as a teacher. This has provided a prominent degree of ethnographic authenticity to the study (Gill \& Johnson, 2010). The author has not only observed practices and reviewed the literature but has also been a participant in the training discussed. In addition, interviews were conducted at length with senior students and teachers of the art. He has adopted ontologically the realist paradigm which is relevant to the understanding of the social processes at work described in this paper.

\section{What is Silat Tua?}

Silat is a blanket term for an indigenous martial art from South-East Asia. The etymology of the word Silat varies from Silap (to make a mistake, i.e. an art of feigning), to Sekilat ('as fast as lightning'), and even Sila, a variation of the word Silsilah, meaning 'chain', which is in reference to its transmission of knowledge from teacher to student as links in a never-ending chain (Farrer, 2009, p. 29). Silat Tua is directly translated as 'old' or 'ancient' Silat. It has been described as the "art of fulfilling the human potential" which is often manifested in practice as "the art of survival" (Zainal Awab \& Sutton N., 2007, p. 21). In Silat Tua, "...the exponent explores all that makes him or her truly human" (Zainal Awab \& Sutton N., 2007, p. 21). Described as the Malay dance of life, Silat Tua does not necessarily follow sets of rigid instructions and endless pre-arranged movement patterns (PMPs) like most traditional martial arts, rather it is an art that begins with "natural movement", focusing "...on the strengths and weaknesses" of the exponent and "...the potential of the individual body" (Zainal Awab \& Sutton N., 2007 p. 22). What is emphasised instead are basic principles and uses of imagery that are actualised in freestyle movement known as a tari ('Dance' in Malay). To visualise this practice the reader is directed to the below link: https://www.youtube.com/watch?v=D60nstxl6fw\&feature=youtu.be (Sutton, L. 2018).

In an attempt to research and understand this art, it is important to recognize that unlike other Asian martial traditions such as Wushu or Karate, Silat Tua's history and 
IImu ('knowledge' in Malay) are passed down orally from one generation to the next (Zainal Awab \& Sutton N., 2007, p. 14). Therefore, pinpointing its true place of origin cannot be definite. However, it is recognized that the art gained popularity in Pattani, a Malay kingdom (from the $15^{\text {th }}$ century until 1909) in what is now a region part of Southern Thailand (Zainal Awab \& Sutton N., 2007, p. 13). As Pattani was constantly at war with the neighbouring kingdom of Siam, many combative developments in the art were made in this region leading Silat Tua to take on another name, Silat Pattani (Zainal Awab \& Sutton N., 2007, p. 13). As challenging as it may be to trace its origins before Pattani, through the art's particular emphasis on the natural movement of its exponents, it is apparent that the influence of the abundant tropics of South-East Asia have had an important role to play in the art's evolution. This notion is explicit in the legend of the art's inception, a testament to Silat Tua's strong relationship with nature.

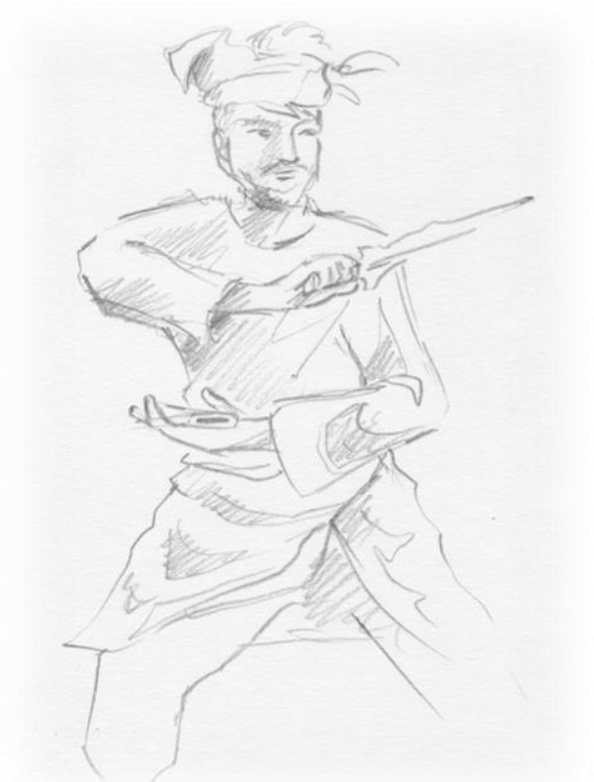

Figure 1. The Warrior. Artist Prunella Ong

The legend (Zainal Awab \& Sutton N., 2007, p. 1719) begins with a wounded warrior, stumbling away from a defeated battle, he wanders into the jungle. Overwhelmed and delirious, the warrior reaches a fast-flowing stream and follows the water upstream until hitting a waterfall then sits beneath the shade of an old tree. While at rest, the warrior notices a lotus flower rushing down the torrent, ending up floating on the pool under the waterfall. The warrior finds something peculiar about the nature of this beautiful lotus. He watches it as it is carried by the current, sometimes sinking under the raging river but bobbing back up again elsewhere. Curious, the warrior picks up a rock and throws it at the lotus dancing on the water. With an accurate throw, the lotus sinks just below the surface, but only to appear elsewhere on the pool unfazed. The warrior, forgetting his wounds, picks up a nearby branch and throws it at the lotus flower. Again, the flower twists and turns, flowing with the current, sinking and rising. Furious, the warrior draws his mighty sword, charges into the water and begins thrusting and hacking at the offending flower but to no avail. The fragile lotus flower only swirls, twirls and twists away, each time appearing further away or too close for an efficient attack. The warrior stumbles back to the old tree, drenched, angry, wounded and tired, defeated in battle and defeated by a lowly flower. With a heart of burning fire, the warrior takes a deep breath, then contemplates and meditates on the experience of his fight with the flower. What followed was an awakening within the warrior which was both simple and profound. The apparent fragility of the lotus flower, the softness and yielding nature of the water combined to create a harmonious form which no force could destroy. The warrior began looking towards all aspects of nature to aid in the 
quest for a holistic yet lethal martial practice. This began with the perceived building blocks of Nature, the four Elements:
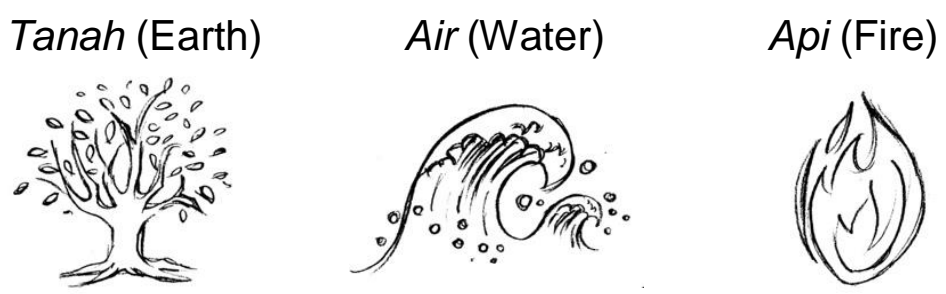

Angin (Wind/Air)

\section{The Four Elements in Practice}

The four Elements, are not only present in the understanding of the world in a number of ancient Asian cultures but has also had an impact on the occidental imagination as expounded in the seminal work of Gaston Bachelard (Macauley, 2011, p. 14). Bachelard sought to "... re-establish imagination in its living role as the guide to human life" (Bachelard, 1943, p. 209) structuring much of his research around the four Elements or what he called "the hormones of imagination" (p. 19). This notion of the imagination being at the forefront of a holistic understanding of the mind and body is reflected repeatedly in Silat Tua, where the Elements are explored in both the environment of training, and in terms of how they are harnessed in the mind and body through the tari.

It is common for the Silat practitioner, or pesilat, to begin first by defining and differentiating the characteristics of each Element. One such way is adhering to a traditional maxim in the IImu of Silat Tua, that the cycle of learning "...takes us [sic] from the outside to the inside and then from the inside to the outside" (Sutton N., 2012, p. 79). This aphorism provides an example of a possible pedagogical structure of Elemental exploration within the art. At first the pesilat, like the warrior discovered in the origins story, searches from the outside, in the interaction between man and Element. The pesilat may be encouraged to train in different terrains, from the grassy plains to sandy beaches, and muddy banks to thick jungle grounds. This interaction is described by Nigel Sutton, co-author of the only published book on Silat Tua, as "Malay Parkour" (Sutton N., personal communication 2017). In this process, the pesilat may learn to move close to the earth for strong grounding (Earth), to work with the breath (Air/Wind) and the natural internal rhythm of the heart (Fire) so as to flow (Water) with Nature, as did the lotus flower in the water. This reinforces a strong discourse (Foucault, 1977; Foucault, 1980) provided by the teacher for the student to internalise these major concepts of the art and offers an intriguing insight into the power of the pedagogic process for Silat Tua. 
In continuation of the maxim, the pesilat then goes "...to the inside", reflecting and drawing conclusions from nature. In the Tanah (Earth) Element, for example, the pesilat gathers from the trees and mountains that movements in Tanah are rooted and strong. It is mostly hard but at times soft, as with the rocks which become sand. Then the Elements are explored in degrees of intensity, for example, how the difference in the fire Element varies between a candle flame and an explosion. As the Elements coexist with one another as part of the Earth's ecosystem, the natural progression in the exploration of the images would fall on the pesilat to mix the Elements. For example, ice, which has the solid characteristics of Earth but is inherently made up of Water, or a Tsunami, which is Wind and Water. Even lightning is a combination of Earth and Fire.

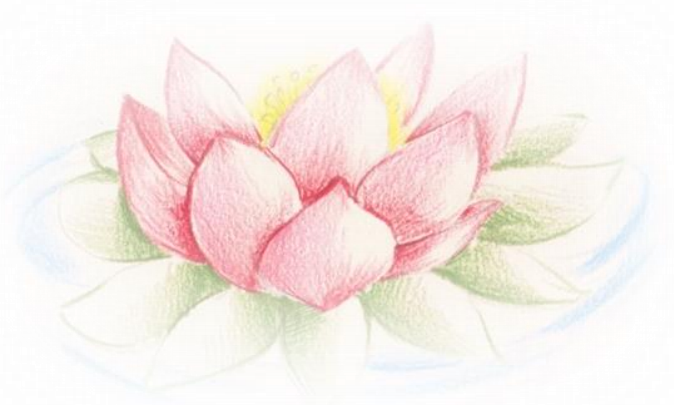

Figure 1. The Humble Lotus Flower. Artist Prunella Ong

To bring the discoveries from the inside back to the outside does not end with the tari, but is brought further in exploration of its uses in combat. Here, the pesilat may be encouraged to discover with a partner, the potential uses of Tanah movement in pulut ('glutinous rice' in Malay), a partnered tari which may not only include grappling and limb locking, but also light sparring. At the end of a training curriculum, a pesilat is required to participate in a graduation ceremony called a Khatam, a concept based on the Islamic ritual completion of a child's first reading of the Qur'an (Zainal Awab \& Sutton N., 2007, p. 121). In his first Khatam, the author was asked to test the skills learnt by sparring with a senior student as well as performing a tari. At certain points in the tari, at the command of the teacher, the author was obliged to pause and explain the purpose and immediate application of the freestyle movement executed. This is played out in an attempt to maintain a strong purpose and martial justification to even the most aestheticized movements found in a tari. In light of this, 'ownership' then becomes an integral concept in the philosophy of Silat Tua as one never stops discovering and learning in the art (Zainal Awab \& Sutton N., 2007, p. 23). 


\section{Understanding the Self through the Elements}

As the pesilat explores an Element in a tari, understanding may be deepened through imagining the ability to manipulate the Element with the body, or imagining the body as being made up of the Element, or both. The body and bodily processes are also seen as being composed of these Elements (Sutton N., 2012, p. 2). Earth correlates with the flesh, bones and muscles, Water with the blood and bodily fluids, Fire with the heart that animates us, and Air/Wind with the respiratory system. Meditative practice is important for establishing the connection between what the Elements mean to a pesilat, and the pesilat's feeling of the Element in the body (Sutton N., 2012, p. 6). Since the development of Mindfulness based stress reduction (MBSR) programs, extensive theoretical writing and empirical research have been done on meditation, the core means of cultivating mindfulness (Davis \& Hayes, 2011, p. 199). Reported benefits of meditation include increased empathy and compassion, and a decrease in stress and anxiety (p. 202-203). In Silat Tua, the use of the Elements in meditation varies slightly from common meditative practices where stillness is encouraged in the body. The Elements meditation includes simple arm movements synchronized with the cycle of breathing, and sometimes chanting of the Element names to strengthen the connection between intellectual and somatic knowing.

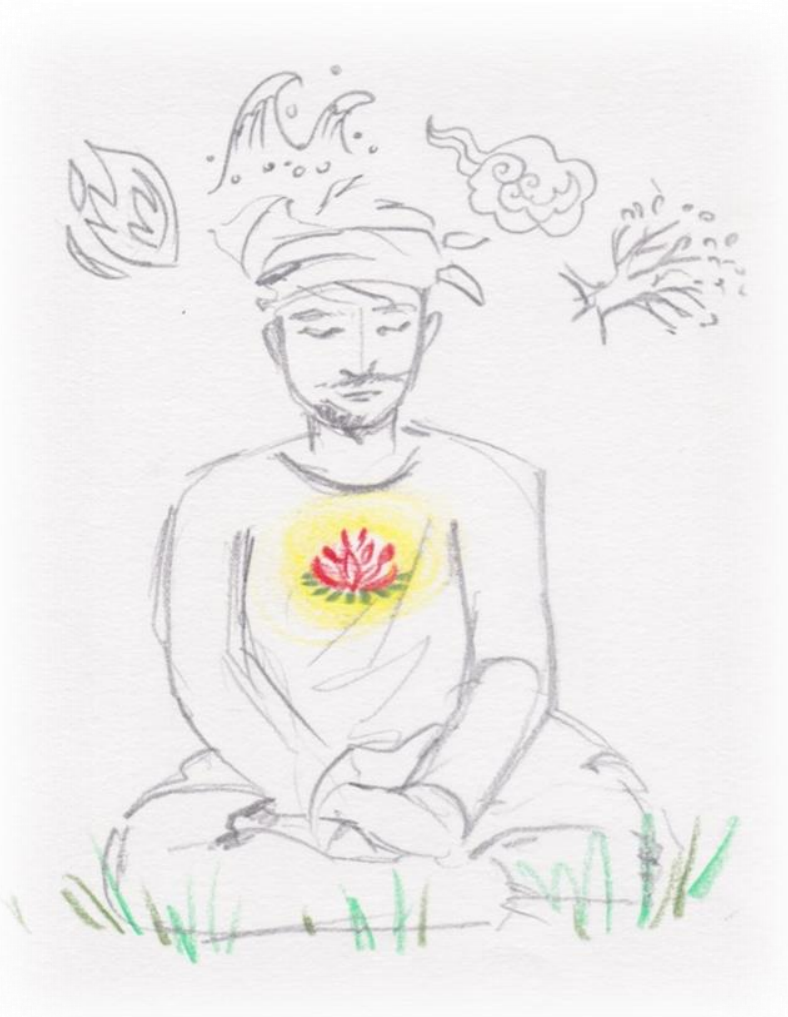

Figure 2. The Meditating Pesilat. Artist Prunella Ong 
The Silat Tua maxim regarding the cycle of learning is reflected once again in this process. By looking inwards through meditation, the connection between being and the Elements are aligned and strengthened. The Pesilat now looks outward at daily behaviour. As many teachers in the lineage have echoed, Silat Tua practice begins "...the moment you step out of the house" (Zainal Awab \& Sutton N., 2007, p. 22). The Pesilat strives to cultivate attitudes such as being accepting of life's trials and tribulations, being natural and relaxed as nature does in its existence, being aware and alert and learning to trust one's instincts (p. 44). These, together with the attributes of humbleness and patience serve as core tenets to the everyday life of the pesilat. However, these changes in self require deep reflection, critical thinking and discipline.

Discovering different aspects of personal behaviour and habitual movement can also be understood through the Elements. In a tari, a pesilat may prefer the use of a particular Element over the rest. Using the conclusions drawn in practice on the nature of each Element, one could deduce, quite generally, that a person indulges considerably in the Earth Element has an immovable nature, maybe even stubborn and opinionated. This adept would then need more practice on the softer Elements such as Water, Wind, or maybe even the spontaneity of Fire. Conversely, those who prefer Wind or Water, may need the grounding of Earth. This concept of relating the Elements to behaviour is not new, the four humours of Hippocratic medicine: blood, yellow bile, black bile and phlegm, which were expanded to the four temperaments: Sanguine, Phlegmatic, Choleric, and Melancholic all correlated with the four Elements (Bachelard \& Farrell, 1977, p. 4; Okal, Ambuyo \& Amukowa, 2012, p. 58). In an example of this type of analysis in application, a student of the author once had difficulty with the Element fire in tari. A predominantly spontaneous and explosive Element, the timid student had difficulty with Fire largely due to her soft-spoken nature. She was uncomfortable with perceived aggression and confrontation, and was partial to legato movement, largely a characteristic of Wind/Air or Water. In the following classes, she was taught not to see fire as an undesirable emotion, namely anger, but as an expression of passion, joy and excitement. Though this concept of comparing behaviour and the characteristics of the Elements are often subjective and lack empirical and rigorous research, in the practice, it is at its core, used as another framework to advocate self-reflection and self-cultivation.

\section{The Elements in the Garden City}

In 2013, the island nation of Singapore commemorated 50 years of a greening campaign which started in 1963 ("City in a Garden", 2018). The city's landscape was designed where greenery was to be a major feature. These pockets of greenery can now be spotted in a network of nature reserves, parks, park connectors and tree-lined 
roads all around the city-state. Despite its small size, Singapore has become one of the world's economic success stories (Clammer, 1982, p. 127). However, in a nation that is constantly seeking economic and technological growth, the only constant variant in Singapore is change. In less than six months, new buildings can be erected while others knocked down. The immediate threat of change, for better or for worse, can be crippling to its people. Perhaps that is why according to a survey conducted across seven Asian nations, the Republic was ranked the lowest in job satisfaction (Chua, 2016). A more recent poll discerned that $45 \%$ of the local population was unhappy with their chosen careers (Teng, 2018). This is where the Elements practice may serve as a physical metaphor for overcoming obstacles one may face in daily life (Sutton, N. 2012, p. 12). As Silat Tua lives in a state of perpetual development, much like Singapore, through constant practice, the pesilat grows to accept that change is a natural course of life (Sutton, N. 2012, p.14). This speaks to the importance of this training with the Elements in dense cities such as Singapore, where a different pace and energy is needed to help balance one's outlook and temperament. In understanding nature outside, one learns more about the nature of the self within and how to navigate through uncertain terrains, both physically and emotionally.

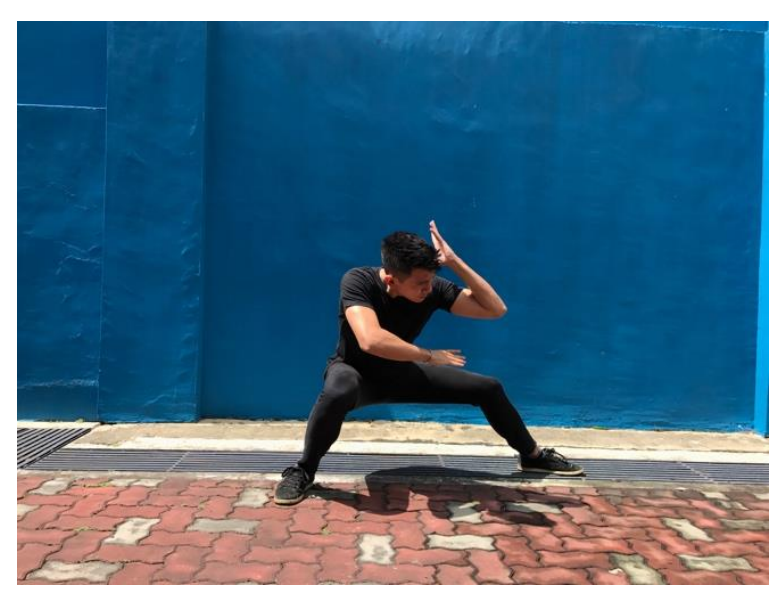

Figure 3. The author doing a Tari In the City. Photo: M. U. Martin.
Although the success of the greening campaign has led to a network of greenery in Singapore, arguably the 'real' Elements of the city manifest themselves differently from their root counterparts. In Singapore, the Earth lives in the concrete pavements and brick walls that direct movement and create boundaries. Water arrives and leaves in the intricate irrigation system that is connected to its source, the sea. Fire as the relentless eye of the sun, in lightning and in kitchen stoves. Wind, as the soft and strong ocean breeze weaving between skyscrapers. These Elements though obvious in the dense tropical jungle are still unavoidable and implicit in the man-made. Therefore, the urban landscape isn't seen as a place to escape from, but embraced in the tari by the pesilat of Singapore.

There are abundant opportunities for future research in the outcomes and benefits of Silat Tua practice regarding the four Elements. Though it is understood that further research into working with local participants in this type training is needed to uncover what the art can truly offer the city-state, questions arise on how the home of the pesilat, or the place a pesilat feels an affinity to, affects the movement of the body in 
the Elements. In other words, is the Silat Tua movement vocabulary culturally specific? As of now, the carriers of the Silat Tua lineage in Southeast Asia have a common understanding of the characteristics of these Elements in practice. However, if one was to teach students who live in a different climate like Alaska, their relationship with the Elements may have different connotations from the people of the tropics. Even within a nation, between island dwellers and people who live inland surrounded by mountains there may be differences. If so, how does the teacher adapt the style, which has had a home in the tropics from its genesis, to suit the natural movement of a pesilat from a different cultural and geographical background?

To summarize, the practice of the Elements imagery form neural patterns that reflect an "... interaction between the organism and the environment" (Damasio, 1999, p. 206). By learning from the Elements apparent in the city itself, Silat Tua becomes not only a physical practice, but a useful tool for living harmoniously in the interaction between the individual and the populated city of Singapore. By linking the imagination to movement, one learns to be strong and resilient as the Earth, to flow and adapt as Water, to be passionate and spontaneous as Fire and to simply breathe, tempering the harshness with Wind. These thoughts reiterate Bachelard's words where the "...imagination has the integrating powers of the tree. It is root and branch. It lives between earth and sky. Imagination lives in the earth and in the wind" (1948, p. 299300). Ultimately, the Silat Tua practice serves as a way to understand, centre and cultivate the self by embodying all the Elements, living as what Bachelard describes as "...the cosmological tree, the tree which summarizes a universe, which makes a universe" (1948, p. 299-300).

\section{References}

Bachelard, G. (1943). L'air et les songes. Paris: J. Corti.

Bachelard, G. (1948). La terre et les rêveries du repos. Paris: J. Corti

Bachelard, G., \& Farrell, E. (1977). Water and dreams by Gaston Bachelard. Ann Arbor, Mich.: University Microfilms International.

Chua, A. (2016). Singapore workers unhappiest in South-east Asia: Survey. TODAYonline. Retrieved 23 January 2018, from http://www.todayonline.com/singapore/singaporeworkers-unhappiest-southeast-asia-survey

City in a Garden. (2018). National Parks Board. Retrieved 25 January 2018, from https://www.nparks.gov.sg/about-us/city-in-a-garden

Clammer, J. (1982). The institutionalization of ethnicity: The culture of ethnicity in Singapore. Ethnic and Racial Studies, 5(2), 127-139. http://dx.doi.org/10.1080/01419870.1982.9993365

Damasio, A. (1999) The Feeling of What Happens: Body and Emotion in the Making of Consciousness, New York: Harcourt Brace.

Davis, D., \& Hayes, J. (2011). What are the benefits of mindfulness? A practice review of psychotherapy-related research. Psychotherapy, 48(2), 198-208. http://dx.doi.org/10.1037/a0022062

Farrer, D. (2009). Shadows of the Prophet (2nd ed.). New York: Springer.

Foucault, M. (1977). The Archeology of Knowledge. London: Tavistock. 
Foucault, M. (1980). Power/Knowledge. Milton Keynes: Harvester Press.

Gill, J., \& Johnson, P. (2010). Research Methods for Managers. London: Paul Chapman Publishing Itd.

Kaplan, E. (1972). Gaston Bachelard's Philosophy of Imagination: An Introduction. Philosophy And Phenomenological Research, 33(1), 1. http://dx.doi.org/10.2307/2106717

Leviton, R. (1994). The Barefoot Philosopher of the Imagination: Gaston Bachelard's Reverie of the Elements. Blue Room Consortium. Retrieved 15 August 2017, from http://www.blueroomconsortium.com/pdfs/article_the-barefoot-philosopher.pdf

Macauley, D. (2011). Elemental philosophy. Albany, N.Y: SUNY Press.

Martin, M. (2018). Cross boundary artists: She's into Chinese ink painting, he's into Malay silat. Channel News Asia. Retrieved 26 January 2018, from https://www.channelnewsasia.com/news/lifestyle/cross-boundary-artists-she-s-intochinese-ink-painting-he-s-into-7606254

Sutton, L. (2014). The Dance of Life (bachelor's thesis), LASALLE College of the Arts, Singapore

Sutton, L. (2018). Silat Tua: Elements Tari. Performance/Demonstration. https://www.youtube.com/watch?v=D60nstxl6fw\&feature=youtu.be

Sutton, N. C. (2012). IImu: The way of the Malay Shaman. Unpublished manuscript.

Okal, B., Ambuyo, B., \& Amukowa, D. (2012). The Functionality of Four Temperaments and Communication Theories towards the Realisation of Peaceful General Elections in Kenya. Journal Of Sociological Research, 3(1). http://dx.doi.org/10.5296/jsr.v3i1.2012

Teng, A. (2018). Survey finds $45 \%$ of S'poreans unhappy at work in 2017. TODAYonline. Retrieved 25 January 2018, from https://www.todayonline.com/singapore/surveyfinds-45-cent-singaporeans-unhappy-work-slight-improvement-last-year

Zainal Abidin Shaikh Awab, \& Sutton, N. C. (2007) Silat Tua: The Malay Dance of Life. Kuala Lumpur: Azlan Ghanie. 